\title{
Byl, Julia, Antiphonal Histories: Resonant Pasts in the Toba Batak Musical Present. Wesleyan
University Press: Middletown,
Connecticut
}

Margaret Kartomi

Monash University, Australia email: margaret.kartomi@monash.edu

The Toba Batak ethno-lingual group who live around the Samosir Island in the province of North Sumatra are well-known throughout the world as a very musical people who like to sing together in their coffee shops and have produced many famous groups of musicianssuch as the popular singer Gordon Tobing. Some of their popular folk songs - such as "Sing Sing So" - have become so widely known that they have acquired national status. Commercial recordings of Batak Toba songs are widely available in Indonesia's record stores.

However their ancient traditional musical traditions are much less known and understood. Unlike the gamelan music of Central and West Java and Bali, detailed ethnomusicological research ofToba musical genres has been minimal. Partly due to the lack of infrastructure and difficulty of travelling around its extensive terrain, sustained research in Toba areas began as late as the 1970s, a half century after Javanese and Balinese musicresearch began. Although a German writer - R. von Heintze-had described the religious functions of some of the traditional music in the largely Lutheran Toba Batak area as early as 1909, and Claire Holt and Rolf de Mare had filmed some of the dances in the Bataklands in 1939 (Holt 1971), a representative collection of Toba archival music recordings was madeonly in the 1970s and 1980sby the German scholar Artur Simonand issued on compact disc by the Museum fuerVoelkerkunde in Berlin, and Simon also published some articles on the music,e.g. in 1991. Another German scholar, Rainer Carle, published on Batak opera in 1987 and 1990, and a Japanese scholar Yoshiko Okazaki researched Toba Batak music in the Catholic churches in 1994, while a Batak scholar-musician MaulyPurba published on the gondangsabangunan ensemble music and its use in church settings in 2002, 2002-3, 
and 2005. In addition, Philip Yampolsky issued aselection of musics of Toba and other Batak groups on the Smithsonian Folkways label in 1982. ${ }^{1}$

This charming book about the history and meaning of the Toba Batak music culture is therefore most welcome. It is the first book-length ethnography of Toba Batak music, dance and theatre performance, which it views as a legacy of the Toba's global history as well as a vital expression of their local experience. It takes cognisance of the fact that the Bataklands have been located on an important international trade route over the past one and a half millennia, and have thus been exposed to considerable culture contact with neighbouring Malays, Indians, Perso-Arabic peoples, and - through colonisation and Christian proselytisation - Europeans. The author draws on her extensive collection of oral histories and local myths collected in the field to show how Toba musical performances document their diverse roots.

Thus, Byl argues, there are many histories of Toba musical genres, ranging from the centuries-old tuned drum and gong-chime ensembles of former Hindu times through nineteenth century Lutheran hymns and brass band music to global musics, as manifested for example in the adoption of Jimmie Rodgers' yodelling techniques in their folk and popular songs.

The book adopts what its author calls a "hybrid methodology". It combines a vertical/ historical exploration of the contemporary music traditions with a horizontal/ chronological analysis of "the place where historiography meets ethnography" in order to discover "what is behind and above the traditions, not just how they unfold chronologically" (pp. 20, 22).Byl describes the interaction between the vertical and the horizontal as "antiphonal" in their response to and affirmation of each other (as opposed to the word's Greek meaning of "voices in opposition").

The first part of the book uses family histories to reveal the ways in which Toba musical and cultural practices have engaged with the global and local past, using stories of the ancestors to reveal what they know about the Indic and the Islamic pasts as well as the colonial and the national. The second part investigates the Toba habit of looking back to interpret the present. Focusing on select performances, the author aims to show how multiple Toba histories are revealed in the performative moment through the interpretations of the participants.

In short, Byl's bookis highly recommended as an original and vividly written reflexive autobiography that is largelybased on personal reflections and stories of the Toba people whomByl has met over the course of her fieldwork.

Finally, ethnomusicological research on other Batak sub-groups includes A.D. Jansen's thesis on Simalungun Batak music (1980) and the Muslim Angkola and Mandailing sub-groups in the southwest of the province (Kartomi 2012,and a pair of prize-winning vinyl discs on the BaerenreiterMusicaphone label 1983 a, b). Music of the Pak-Pak Dairi in the northeast was studied by Lynette Moore at Monash University (e.g.1979).

1 Details of these references are listed in Margaret Kartomi, Musical Journeys in Sumatra, University of Illinois Press, 2012. 


\section{REFERENCES}

Carle, Rainer, ed. (1990), Opera Batak: Das Wandertheater der Toba-Batak in Nord Sumatra, 2 vols., Hamburg: Dietrich Reimer Verlag.

Heinze, R, von. (1909), “Ueber Batak-Musik”, in Nordsumatra, vol 1, 373-381. Berlin: D. Reimer.

Jansen, A.D. (1980), “Gondang Music; its structure and function in Simalungun Batak Society in Sumatra", PhD diss., University of Washington.

Kartomi, Margaret. (1983a), The Angkola people of Sumatra,BaerenreiterMusicaphone vinyl disc, BM30SL2568.

(1983b),The Mandailing People of Sumatra,BaerenreiterMusicaphone vinyl disc, BM30SL2567.

(2012), “The Mandailingraja tradition in Pakantan, Chapter 11, Musical Journeys in Sumatra, Urbana: University of Illinois Press, 221-250.

Moore, Lynette. (1979), "Songs of the Pakpak of North Sumatra", PhD diss., Monash University.

Okazaki, Yoshiko. (1998), "Liturgical music among the Toba Batak people of North Sumatra: the Creation of a New Tradition. Crossroads: an Interdisciplinary Journal of Southeast Asian Studies, 55-74.

(1994), "Music, identity and religious change among the Toba Batak people of North Sumatra", PhD diss., University of California, Los Angeles.

Purba, Mauly. (2003), “GondangSabangunan Ensemble Music of the Batak Toba People; Musical Instruments, Structure and Terminology", Journal of Musicological Research 21, nos 1-2, 21-72.

Simon, Artur. (1991), “Gondang, Gods and Ancestors, Religious Implications of Batak Ceremonial Music, Yearbook for Traditional Music 25, 81-88.

Yampolsky . (1982), (vol4) Music of Nias and North Sumatra: Hoho, GendangKaro, Gondang Toba,Music from Indonesia 4, Smithsonian Folkways Recordings 40420. 